\title{
SUSTAINABLE GENDER EQUITY INFLUENCED BY AN AMERICANIZED LEBANESE PEDAGOGY
}

\author{
Al-Abbas $\mathrm{M}^{*}$ and Oneissi J \\ Lebanese American University, Lebanon
}

\begin{abstract}
Gender representation and equity is a quintessential aspect of higher education, as research has shown higher level of research engagement between students and faculty of similar ethnicity, culture, or gender. Therefore, to promote increased student engagement and interest in pursuing graduate education across these groups, proper efforts and policies should be put in place to provide equitable and heterogenous representation. This study quantifies the importance of gender representation by employing a bibliometric analysis of female and male student engagement in research led by female or male faculty counterparts. The scope is the Lebanese American University and respective scholarly publications, due to its unique dichotomy of being an American-charted university, with American policies and international faculty, in a patriarchal Middle Eastern country. Our findings demonstrate that in 2020,72.7\% of publications with a female last author had a female first author, while only $52.4 \%$ of male last authors had a female first author. Whereas in 2021, the numbers decreased to $57.1 \%$ and $33.3 \%$, respectively, likely due to COVID-19 prompting a decrease in published articles in female-led subjects. The elevated frequency of collaboration between first and last female authors illustrates increased engagement between students and faculty of the female gender, heightened by an effort to combat existing inequalities in representation. This is furthered by the comparable frequency of male and female student collaborations with male last authors, which could indicate some form of allyship to promote gender equity in research groups.
\end{abstract}

Keywords: gender equity, women in science, authorship, allyship, scholarly publication

\section{Introduction}

By almost any metric, women have made great gains in closing the scientific gender gap. However, female researchers around the world continue to face major challenges (Shen, 2013). Female researchers are often undervalued, often receiving $80 \%$ of their male counterparts' salaries (West et al., 2013), and underrepresented when it comes to hiring practices, promotions, publications in prestigious journals, and authorship positions (Conley \& Stadmark, 2012; West et al., 2013). Even as the number of female researchers engaged in scholastic pursuits continues to rise across all fields and disciplines, we continue to observe increasing instances of inequity (Bernardi et al., 2020).

Gender inequity in academia is especially egregious, as previous studies have shown that gender inequity stifles scientific advancement while inclusive scholarly teams are more productive (Nielsen et al., 2017; Sheltzer \& Smith, 2014). Therefore, to better scientific advancement and engagement, inclusivity must be a cornerstone of team formation. Inclusivity must span the scientific gender gap through the promotion of leadership among female researchers. Leadership has many forms in the scientific community, ranging from assuming leadership positions in academia (deanship, chairmanship, etc.) to leading laboratories and research teams. In fact, the latter has often been 
described as the stepping stone for any leadership position and a criterion of many faculty promotion/tenureship matrices (West et al., 2013). Therefore, to truly measure the involvement, inclusivity, and leadership of female researchers, one must investigate their scholastic authorship.

However, gender inequity in the scientific community is not constant across countries and cultures. Studies have shown that different countries, cultures, and communities have varying levels of inequity based on gender productivity and career lengths which is often determined by a culture unique to each country (Huang et al., 2020). Hence, when considering to investigate gender inequity, it is vital to consider the culture and location of the investigated data. In particular, some cultures are more patriarchal and would rather have women, in general, and researchers, in particular, serve different gendered roles that might often cut their careers short and keep them from assuming leadership roles (Huang et al., 2020; Metcalfe, 2008; Morley, 2014).

This work aims to conduct an investigation into scholastic authorship of both genders in Lebanon, a country in the Middle East. Lebanon's culture is especially unique as it is conservative and patriarchal, but retains some liberal and feminist ideals; these ideals are exemplified by chartered universities in Lebanon that apply policies and provide relevant support systems, allowing them to become melting pots of culture. One such university is the Lebanese American University (LAU), where American gender policies (equal opportunity, anti-discrimination policies, etc.), as well as liberal and feminist ideals are imported and amalgamated with the local Lebanese culture. LAU is especially interesting as it is a Master's College with no Ph.D. programs and a relatively low number of master's degrees awarded annually. Therefore, student engagement is dependent primarily on undergraduates and a small graduate student body but allows the investigation of the mentor/mentee relationship across genders and several publications. Furthermore, LAU is considered a medium sized institution with little to no overlap between faculty specialties according to their Ph.D. theses. However, faculty specialties span a broad range of different disciplines under Social Sciences \& Management, Engineering, Natural Sciences, Medicine \& Life Sciences, and Arts \& Humanities.

\section{Methods}

\section{Gender and Author Leadership}

Scholarly leadership can be quantified through an investigation of author gender composition on published works. Traditionally, the first author contributes most and also receives most of the credit, whereas the position of subsequent authors is usually decided by contribution, alphabetical order, or reverse seniority (Tscharntke et al., 2007). However, as alphabetical order authorship is rarely ever adopted outside the disciplines of economics and high energy physics (Kosmulski, 2012), articles as such are considered negligible. Furthermore, whether by contribution or seniority, it is widely considered that the last author is the individual who conceived, supervised, and is the primary correspondence for the scholarly work, especially in scientific publications (West et al., 2013; Wren et al., 2007). Subsequently, this work focused on the gender of the first and last authors of published works. Both the first and last authors of published works had to be affiliated with the Lebanese American University to be considered. 


\section{Labelling Gender}

To label and categorize the gender of the authors, a natural language processing (NLP) algorithm. The algorithm utilized a publicly available name-to-gender API named "genderize" [genderize.io], the API leverages a dataset of 114.5 million international names. However, given that our data is sourced from the Lebanese American University, located in Lebanon, we restricted the algorithm to the Lebanese names dataset as to avoid culturally specific names from being miscategorized. As an additional measure we queried, at random, several names and confirmed their gender based on social media (LinkedIn), faculty profiles, and Google Scholar. The authors would also like to acknowledge that while gender is a spectrum, recognizing genders beyond the female and male categorization, we adhered to traditional concepts of gender. Having done so allowed our results to be comparable to that of previous works.

\section{Dataset}

The dataset is exported from Clarivate's Incites database, narrowing the search to publications made by the Lebanese American University during the years of 2020 and 2021. Afterwards, the first and last author's affiliations are verified to correspond with that of LAU, if either author positions are not affiliated, that row is automatically deleted. After the verification, the datasets are exported to the "genderize" API where they are categorized as male or female. A full breakdown of the dataset can be found in appendix.

\section{Results and Discussion}

InCite's database indexes 334 articles by LAU between 2020 and 2021. Once our methodology was applied to that database, we curated 84 articles that had first and last authors affiliated with LAU, with 43 published in 2020 and 41 published in 2021. In 2020, 72.7\% of articles with a female last author had a female first author, while $52.4 \%$ of articles with a male last author had a female first author. Whereas in $2021,57.1 \%$ of articles with a female last author had a female first author and only $33.3 \%$ of articles with a male last author had a female first author. The gender distribution of research teams is shown in Figure 1. 


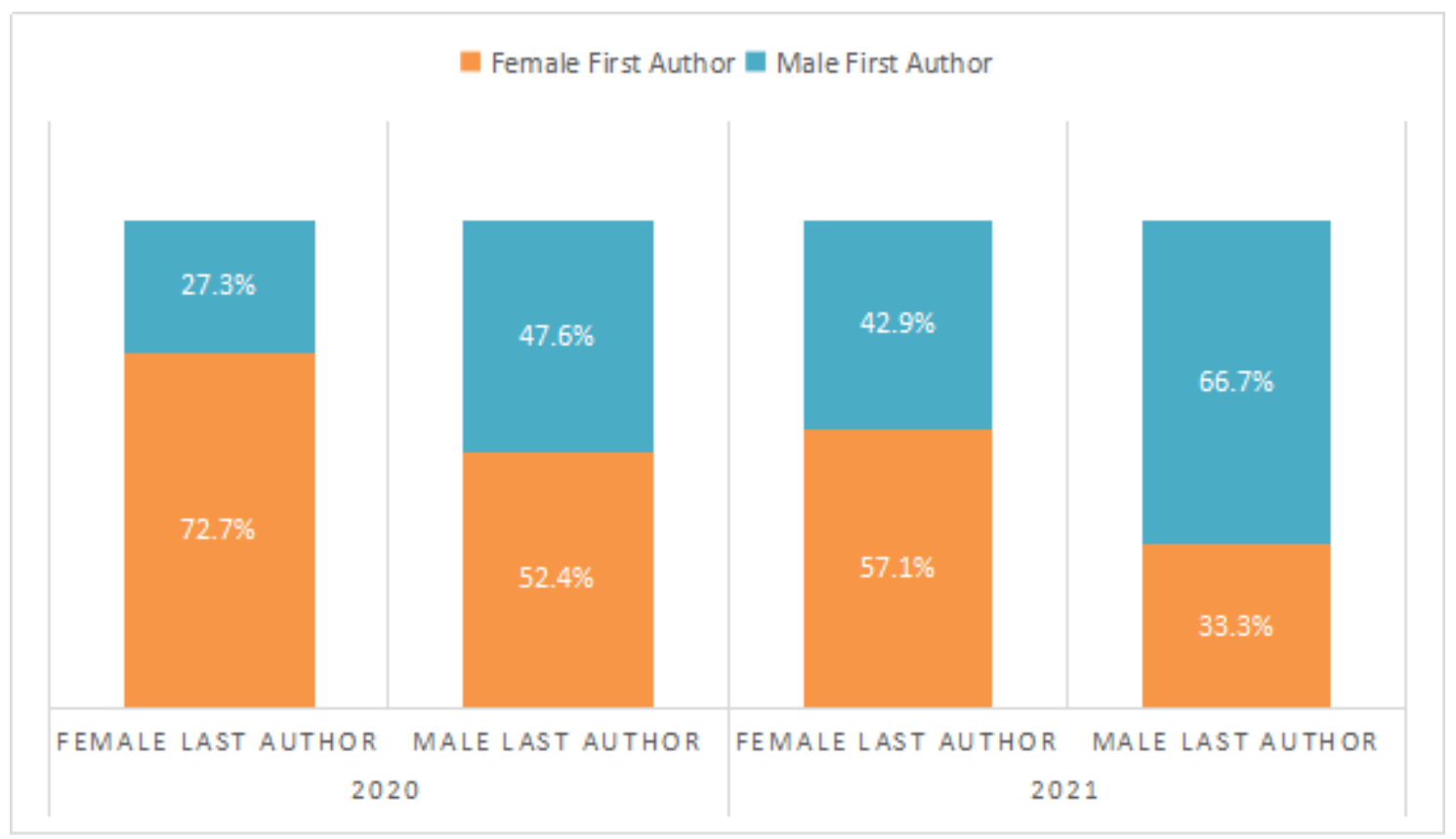

Figure 1: Distribution of first and last author teams' gender between the years of 2020 and 2021

This gender representation hints toward the decision-making process of each of the male and female last authors. The applied methodology allows us to curate articles where the first and last authors are affiliated with LAU, avoiding high multi-authored publications, which usually have international influence (Al-Abbas \& Saab, 2020a, 2020b). These articles are often written by student first authors and faculty last authors, with only three instances of both authors being faculty. Therefore, we can draw a mentor and mentee relationship between the first author (mentee) and last author (mentor). As such, last authors engage with first authors with the aim of supporting and guiding them as well as leveraging their skills and capabilities.

Our results show that female last authors are likely favoring other females to mentor in an effort to facilitate their scholarly experience. Since they have themselves experienced the obstacles that come with being a woman in research (Nielsen et al., 2017; West et al., 2013), they are likely attempting to alleviate the struggles of qualified female researchers by working with them on articles and amplifying their portfolio. This decision could be taken as an initiative by individual female researchers in order to combat the existing inequalities women experience in research. On the other hand, male last authors could be acting as allies, having recognized their role and responsibility in eliminating such inequalities by supporting female and male researchers fairly. This incorporation of female researchers under the mentorship of male researchers, as well as their counterparts, provide for heterogeneous research groups, which are found to achieve higher scholastic productivity and engagement, making way for greater scientific advancements.

In order to understand the shift in gender distribution during 2021, we must first dissect the scholarly works by subject. Leveraging the All-Science-Journal-Classification (ASJC), we are able to divide journals into disciplines and fields. Then, we grouped the journals based on five broad subject categories: (1) Business and management, (2) Engineering, (3) Medicine \& life sciences, (4) Natural sciences, and (5) Social sciences. The division allows us to visualize the gender distribution, whether 
first or last author, across the varying disciplines to investigate if genders are equitably represented in all disciplines. The distribution is shown in Figure 2.

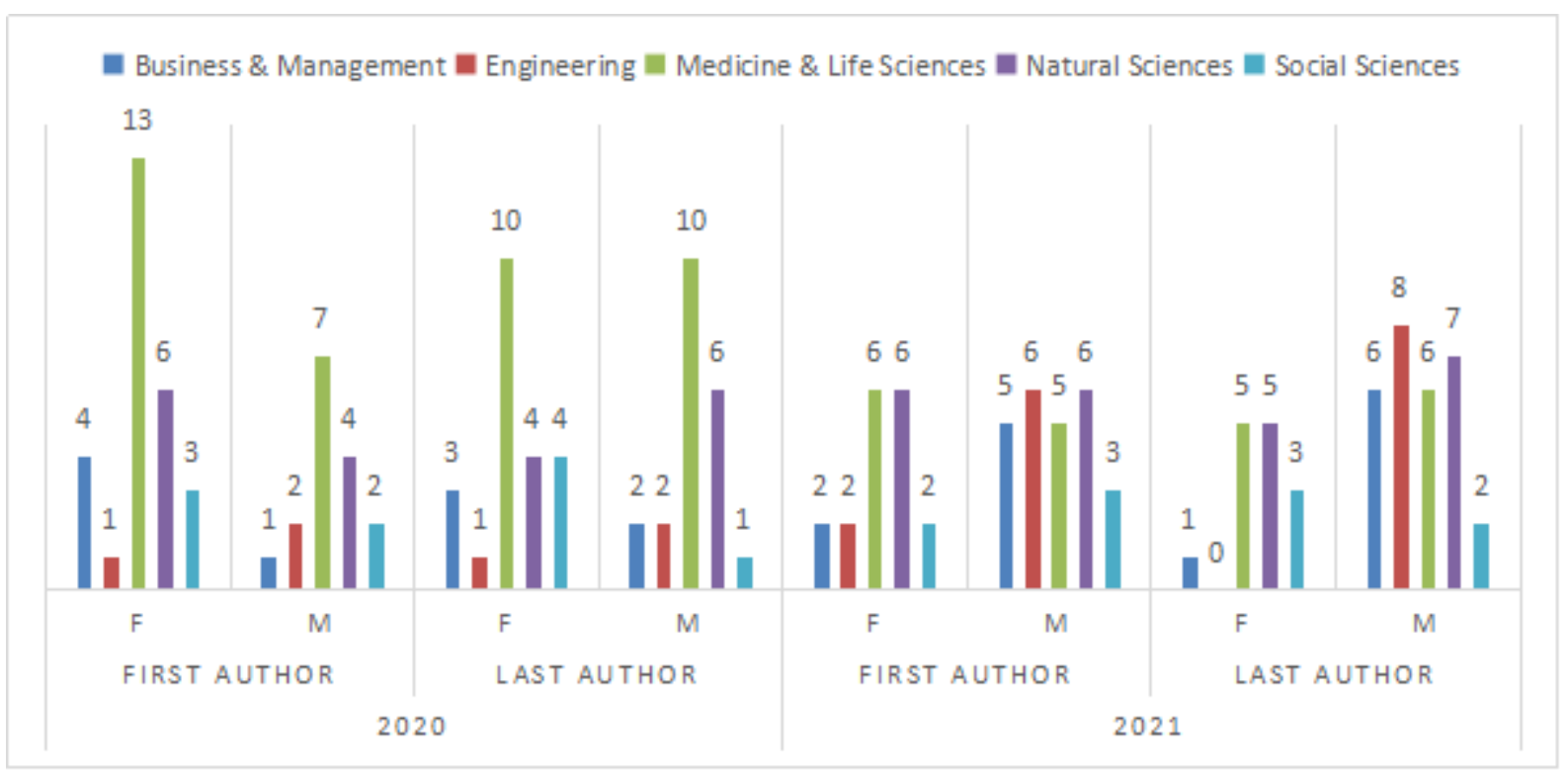

Figure 2: Gender distribution of first and last author in all five broad subject categories across 2020 and 2021.

The data indicates a 36.4\% and 33.3\% decrease, between 2020 and 2021, in female last and first author engagement, respectively. Furthermore, this decrease could be attributed to a decrease in the number of engaged authors in Medicine \& life science, a subject that is dominated by female authorship in both years but has a severely decreased volume of publication in 2021 compared to 2020. The likely justification behind the decreased productivity of that field as opposed to increased productivity in others is the COVID-19 lockdowns that restricted access to labs, reagents, and materials that are pivotal to conducting research in the field of life sciences. In light of this, setting aside the influence of the COVID-19 lockdown on research output, these distributions reveal the unique environment established in LAU, born out of the Lebanese culture and American policies.

Education in Lebanon is held at a high regard for both women and men, which is why the enrollment of women and men in education is almost equal, with women even forming the majority at some levels (Bacha \& Bahous, 2013; USAID, 2019). Women are encouraged to pursue their education although the reason for this support could be vested in patriarchal assumptions, such as the prospect of finding a husband while at university. Thus, it is apparent that while women do attend tertiary education at the same rate as men, the support they receive does not extend to engaging in research or launching a career in academia and is rather restricted only to the goal of getting a degree. The patriarchal and misogynistic aspects of the Lebanese culture and society still constitute a setback preventing women from achieving equitable representation and involvement in academia or research, where they are not provided the same opportunities as men due to social and economic constraints.

However, the policies set in LAU as an American-chartered university have helped counter that while leveraging the Lebanese gendered support for enrollment in education. One such policy is Title IX, a 1972 education amendment to the American Civil Rights law that prohibits discrimination on the basis of sex in any federally funded education program or activity and seeks to ensure gender equality in education (Stratcom, 2019). Title IX goes beyond protecting individuals from discrimination and harassment to also target systemic and structural issues of inequality. Some of the activities led by this 
office include advocating for equity and inclusion throughout the university, its projects, and activities, training students, faculty, and staff on rights and responsibilities toward gender equity and inclusion, and receiving complaints regarding instances of discrimination or harassment in order to hold perpetrators accountable. As a result, this office not only helps create an environment that women can feel safe in, but also enables women to push forward beyond simply attaining a degree in order to be more involved in academic research and scholarly work.

\section{Conclusion}

This work has assessed gender equity within a higher education institution located in a patriarchal society and influenced by American policies and feminist ideals. We found that female faculty in LAU often display comradery and mentor female students at a much higher rate than their male counterparts. In turn, the male faculty members have demonstrated allyship towards female students as well. However, this phenomenon seems to be tethered to the productivity of fields, as a decrease in medicine \& life sciences publications in 2021 yielded a decrease of engagement by females in research overall. Therefore, work is still needed to promote inclusivity and engagement beyond the bounds of departments and disciplines. Looking at engineering, where in 2021 no publications had a female last author, this likely, in turn, affected the amount of female first authors engaged in engineering research. We also acknowledge the effect a title IX office had in ensuring that healthy and non-exploitative mentor-mentee relationships are feasible and sustainable.

\section{Declaration of Interest Statement}

The authors declare that they have no conflict of interests.

\section{References}

Abi-Gerges, A., Dagher-Hamalian, C., Abou-Khalil, P., Chahine, J. B., Hachem, P., \& Khalil, C. (2020). Evaluation of waterpipe smoke toxicity in C57BL/6 mice model. Pulmonary Pharmacology and Therapeutics, 63, 101940. https://doi.org/10.1016/j.pupt.2020.101940

Ahdab, R., Mansour, A. G., Khazen, G., El-Khoury, C., Sabbouh, T. M., Salem, M., Yamak, W., Ayache, S. S., \& Riachi, N. (2019). Cathodal Transcranial Direct Current Stimulation of the Occipital cortex in Episodic Migraine: A Randomized Sham-Controlled Crossover Study. Journal of Clinical Medicine, 9(1), 60. https://doi.org/10.3390/jcm9010060

Al-Abbas, M., Fawaz, W., Ghajar, R., Rjeily, C. A., Ouaiss, I., Nakad, Z., Nasr, G. E., \& Saab, S. S. (2020). Toward an Improvement of Engineering Teaming Skills through an In-House Professionalism Course. IEEE Transactions on Education, 63(4), 273-282. https://doi.org/10.1109/TE.2020.2980379

Al-Abbas, M., \& Saab, S. S. (2020a, October 22). The Impact of Collaborative Research: A Case Study in a Developing Country. $4^{\text {th }}$ International Symposium on Multidisciplinary Studies and Innovative Technologies, $\quad$ ISMSIT $2020 \quad$ - $\quad$ Proceedings. https://doi.org/10.1109/ISMSIT50672.2020.9254613

Al-Abbas, M., \& Saab, S. S. (2020b, December 30). On the Impact of Multi-Authorship Scholarly Publications. Proceedings of IEEE International Conference on Advent Trends in Multidisciplinary Research and Innovation, ICATMRI 2020. https://doi.org/10.1109/ICATMRI51801.2020.9398438

Al-Abbas, M., \& Saab, S. S. (2021). Quantifying Publisher's Competence Through Scholarly Engagement. Publishing Research Quarterly, 1-10. https://doi.org/10.1007/s12109-021-09813-w 
Al-Alam, J., Baroudi, F., Chbani, A., Fajloun, Z., \& Millet, M. (2020). A multiresidue method for the analysis of pesticides, polycyclic aromatic hydrocarbons, and polychlorinated biphenyls in snails used as environmental biomonitors. Journal of Chromatography A, 1621. https://doi.org/10.1016/j.chroma.2020.461006

Al Haddad, M., El-Rif, R., Hanna, S., Jaafar, L., Dennaoui, R., Abdellatef, S., Miskolci, V., Cox, D., Hodgson, L., \& El-Sibai, M. (2020). Differential regulation of rho GTPases during lung adenocarcinoma migration and invasion reveals a novel role of the tumor suppressor StarD13 in invadopodia regulation. Cell Communication and Signaling, 18(1), 1-20. https://doi.org/10.1186/s12964-020-00635-5

Al Khoury, C. (2021). Molecular insight into the endophytic growth of Beauveria bassiana within Phaseolus vulgaris in the presence or absence of Tetranychus urticae. Molecular Biology Reports, 48(3), 2485-2496. https://doi.org/10.1007/s11033-021-06283-3

Antar, E., \& Elkhoury, M. (2020). Casing optimization of a Savonius wind turbine. Energy Reports, 6, 184-189. https://doi.org/10.1016/j.egyr.2019.08.040

Antounian, C., Dah, M. A., \& Harakeh, M. (2021). Excessive managerial entrenchment, corporate governance, and firm performance. Research in International Business and Finance, 56, 101392. https://doi.org/10.1016/j.ribaf.2021.101392

Aoun Barakat, K., Dabbous, A., \& Tarhini, A. (2021). An empirical approach to understanding users' fake news identification on social media. Online Information Review. https://doi.org/10.1108/OIR-082020-0333

Assaad, J. J., Nasr, D., Gerges, N., \& Issa, C. (2021). Use of Soft Computing Techniques to Predict the Bond to Reinforcing Bars of Underwater Concrete. International Journal of Civil Engineering, 19(6), 669-683. https://doi.org/10.1007/s40999-020-00598-1

Assaker, G., O'Connor, P., \& El-Haddad, R. (2020). Examining an integrated model of green image, perceived quality, satisfaction, trust, and loyalty in upscale hotels. Journal of Hospitality Marketing and Management, 29(8), 934-955. https://doi.org/10.1080/19368623.2020.1751371

Assi, C., Bonnel, F., Mansour, J., Mares, O., \& Yammine, K. (2021). Morphometric analysis of all 24 hip muscles: A cadaveric study of 18 hip specimens with proposal of a new classification of muscles. Surgical and Radiologic Anatomy, 43(1), 63-72. https://doi.org/10.1007/s00276-020-02539-y

Assi, C., Mansour, J., Samaha, C., Ajjoub, S., \& Yammine, K. (2020). A single antegrade intramedullary k-wire for fifth metacarpal neck fractures. European Journal of Trauma and Emergency Surgery, 46(2), 389-395. https://doi.org/10.1007/s00068-018-01073-2

Bacha, N. N., \& Bahous, R. (2013). Cultures of Learning in Academia: A Lebanese Case Study. In Researching Cultures of Learning (pp. 116-135). Palgrave Macmillan UK. https://doi.org/10.1057/9781137296344_7

Bernardi, K., Lyons, N. B., Huang, L., Holihan, J. L., Olavarria, O. A., Martin, A. C., Milton, A. N., Loor, M. M., Zheng, F., Tyson, J. E., Ko, T. C., \& Liang, M. K. (2020). Gender Disparity in Authorship of Peer-Reviewed Medical Publications. American Journal of the Medical Sciences, 360(5), 511-516. https://doi.org/10.1016/j.amjms.2019.11.005

Berro, J., Akel, M., Hallit, S., \& Obeid, S. (2021). Relationships between inappropriate eating habits and problematic alcohol use, cigarette and waterpipe dependence among male adolescents in Lebanon. BMC Public Health, 21(1), 1-8. https://doi.org/10.1186/s12889-021-10184-2

Bilen, M., Ibrahim, P., Barmo, N., Abou Haidar, E., Karnib, N., El Hayek, L., Khalifeh, M., Jabre, V., Houbeika, R., Stephan, J. S., \& Sleiman, S. F. (2020). Methionine mediates resilience to chronic social defeat stress by epigenetic regulation of NMDA receptor subunit expression. Psychopharmacology, 237(10), 3007-3020. https://doi.org/10.1007/s00213-020-05588-8

Bouclaous, C. H., Alrazim, A., Chababi, J., Jamaleddine, W., Nassar, E., Maalouf, A., Dakour Aridy, S., Naccache, M., Abboud, D. M., Assi, M., \& Slika, M. (2021). Association between sources of 
sexuality education, sexual beliefs and behaviours in Lebanese young adults: a university-based crosssectional study. Sex Education, 21(1), 1-12. https://doi.org/10.1080/14681811.2020.1722624

Bouri, E., Gupta, R., Pierdzioch, C., \& Salisu, A. A. (2021). El Niño and forecastability of oil-price realized volatility. Theoretical and Applied Climatology, 144(3-4), 1173-1180. https://doi.org/10.1007/s00704-021-03569-1

Bouri, E., Lucey, B., Saeed, T., \& Vo, X. V. (2021). The realized volatility of commodity futures: Interconnectedness and determinants. International Review of Economics and Finance, 73, 139-151. https://doi.org/10.1016/j.iref.2021.01.006

Bouri, E., Saeed, T., Vo, X. V., \& Roubaud, D. (2021). Quantile connectedness in the cryptocurrency market. Journal of International Financial Markets, Institutions and Money, 71, 101302. https://doi.org/10.1016/j.intfin.2021.101302

Chmaisani, W., \& Elmoussaoui, S. (2021). Theoretical study of laser cooling of the TlF+molecular ion. Physical Chemistry Chemical Physics, 23(2), 1718-1726. https://doi.org/10.1039/d0cp05575a

Conley, D., \& Stadmark, J. (2012). Gender matters: A call to commission more women writers. In Nature (Vol. 488, Issue 7413, p. 590). Nature Publishing Group. https://doi.org/10.1038/488590a

Dabbous, A., \& Tarhini, A. (2021). Does sharing economy promote sustainable economic development and energy efficiency? Evidence from OECD countries. Journal of Innovation and Knowledge, 6(1), 58-68. https://doi.org/10.1016/j.jik.2020.11.001

Dagher-Hamalian, C., Stephan, J., Zeeni, N., Harhous, Z., Shebaby, W. N., Abdallah, M. S., \& Faour, W. H. (2020). Ghrelin-induced multi-organ damage in mice fed obesogenic diet. Inflammation Research, 69(10), 1019-1026. https://doi.org/10.1007/s00011-020-01383-5

Di Lernia, V., \& Ricci, C. (2015). Fluconazole-induced acute generalized exanthematous pustulosis. Indian Journal of Dermatology, 60(2), 212. https://doi.org/10.4103/0019-5154.152572

Diab, S., Yu, M., \& Wang, S. (2020). CDK7 Inhibitors in Cancer Therapy: The Sweet Smell of Success? In Journal of Medicinal Chemistry (Vol. 63, Issue 14, pp. 7458-7474). American Chemical Society. https://doi.org/10.1021/acs.jmedchem.9b01985

Dibeh, G., Fakih, A., Marrouch, W., \& Matar, G. (2021). Who Cares About Environmental Quality in the MENA Region? Social Indicators Research, 1-27. https://doi.org/10.1007/s11205-021-02667-x

Djoundourian, S. S. (2021). Response of the Arab world to climate change challenges and the Paris agreement. International Environmental Agreements: Politics, Law and Economics, 1-23. https://doi.org/10.1007/s10784-021-09524-9

Doumit, R., Kazandjian, C., \& Militello, L. K. (2020). COPE for Adolescent Syrian Refugees in Lebanon: A Brief Cognitive-Behavioral Skill-Building Intervention to Improve Quality of Life and Promote Positive Mental Health. Clinical Nursing Research, 29(4), 226-234. https://doi.org/10.1177/1054773818808114

EL-CHAMI, D., AL HADDAD, M., ABI-HABIB, R., \& EL-SIBAI, M. (2021). Recombinant anthrax lethal toxin inhibits cell motility and invasion in breast cancer cells through the dysregulation of Rho GTPases. Oncology Letters, 21(2). https://doi.org/10.3892/ol.2020.12424

El-Mais, N., Fakhoury, I., Abdellatef, S., Abi-Habib, R., \& El-Sibai, M. (2021). Human recombinant arginase I [HuArgI (Co)-PEG5000]-induced arginine depletion inhibits ovarian cancer cell adhesion and migration through autophagy-mediated inhibition of RhoA. Journal of Ovarian Research, 14(1). https://doi.org/10.1186/s13048-021-00767-3

El-Rajab, M., \& Abou-Rjeily, C. (2021). Impact of relay placement in three-hop buffer-aided FSO systems: An approximate performance analysis approach. Physical Communication, 45, 101276. https://doi.org/10.1016/j.phycom.2021.101276

El Hajj, C., Walrand, S., Helou, M., \& Yammine, K. (2020). Effect of vitamin D supplementation on inflammatory markers in non-obese lebanese patients with type 2 diabetes: A randomized controlled trial. Nutrients, 12(7), 1-12. https://doi.org/10.3390/nu12072033 
Elaridi, J., Dimassi, H., Al Yamani, O., Estephan, M., \& Hassan, H. F. (2021). Determination of lead, cadmium and arsenic in infant formula in the Lebanese market. Food Control, 123, 107750. https://doi.org/10.1016/j.foodcont.2020.107750

Elaridi, J., Dimassi, H., Estephan, M., \& Hassan, H. F. (2020). Determination of aluminum, chromium, and barium concentrations in infant formula marketed in Lebanon. Journal of Food Protection, 83(10), 1738-1744. https://doi.org/10.4315/JFP-20-003

Eslami, H., Najem, S., Ghanem, D. A., \& Ahmad, A. (2021). The potential of urban distributed solar energy in transition economies: The case of Beirut city. Journal of Environmental Management, 285. https://doi.org/10.1016/j.jenvman.2021.112121

Fakhoury, T. (2021). Refugee return and fragmented governance in the host state: displaced Syrians in the face of Lebanon's divided politics. Third World Quarterly, 42(1), 162-180. https://doi.org/10.1080/01436597.2020.1762485

Farah, M. F., \& Ramadan, Z. B. (2020). Viability of Amazon's driven innovations targeting shoppers' impulsiveness. Journal of Retailing and Consumer Services, 53, 101973. https://doi.org/10.1016/j.jretconser.2019.101973

Farah, M. F., \& Shahzad, M. F. (2020). Fast-food addiction and anti-consumption behaviour: The moderating role of consumer social responsibility. International Journal of Consumer Studies, 44(4), 379-392. https://doi.org/10.1111/ijcs.12574

Farah, N., \& Ghadboun, A. (2021). The MINC proximity function for fractured reservoirs flow modeling with non-uniform block distribution. Oil and Gas Science and Technology, 76, 20. https://doi.org/10.2516/ogst/2020099

Feghali, R., Merhi, G., Kwasiborski, A., Hourdel, V., Ghosn, N., \& Tokajian, S. (2021). Genomic characterization and phylogenetic analysis of the first SARS-CoV-2 variants introduced in Lebanon. PeerJ, 9, 19. https://doi.org/10.7717/peerj.11015

Hanna, R., Abdallah, J., \& Abou-Antoun, T. (2021). A Novel Mechanism of 17-AAG Therapeutic Efficacy on HSP90 Inhibition in MYCN-Amplified Neuroblastoma Cells. Frontiers in Oncology, 10, 1. https://doi.org/10.3389/fonc.2020.624560

Harhous, Z., Faour, W. H., \& El Zein, N. (2021). VIP modulates human macrophages phenotype via FPRL1 via activation of RhoA-GTPase and PLC pathways. Inflammation Research, 70(3), 309-321. https://doi.org/10.1007/s00011-021-01436-3

Hodroj, M. H., Al Bast, N. A. H., Taleb, R. I., Borjac, J., \& Rizk, S. (2020). Nettle tea inhibits growth of acute myeloid leukemia cells in vitro by promoting apoptosis. Nutrients, 12(9), 1-18. https://doi.org/10.3390/nu12092629

Huang, J., Gates, A. J., Sinatra, R., \& Barabási, A. L. (2020). Historical comparison of gender inequality in scientific careers across countries and disciplines. Proceedings of the National Academy of Sciences of the United States of America, 117(9), 4609-4616. https://doi.org/10.1073/pnas.1914221117

Idriss, M., Hodroj, M. H., Fakhoury, R., \& Rizk, S. (2020). Beta-tocotrienol exhibits more cytotoxic effects than gamma-tocotrienol on breast cancer cells by promoting apoptosis via a P53-independent PI3- kinase dependent pathway. Biomolecules, 10(4). https://doi.org/10.3390/biom10040577

Issa, E., Merhi, G., Panossian, B., Salloum, T., \& Tokajian, S. (2020). SARS-CoV-2 and ORF3a: Nonsynonymous Mutations, Functional Domains, and Viral Pathogenesis. MSystems, 5(3). https://doi.org/10.1128/msystems.00266-20

Issa, J. S., \& Habchi, W. (2020). Influence of realistic lubricant density-pressure dependence on the stiffness of elastohydrodynamic lubricated contacts. Journal of Tribology, 142(3). https://doi.org/10.1115/1.4045192

Itani, O. S., \& Chaker, N. N. (2021). Harnessing the Power Within: The Consequences of Salesperson Moral Identity and the Moderating Role of Internal Competitive Climate. Journal of Business Ethics, 1, 3. https://doi.org/10.1007/s10551-021-04794-4 
Jaafar, L., Fakhoury, I., Saab, S., El-Hajjar, L., Abou-Kheir, W., \& El-Sibai, M. (2021). StarD13 differentially regulates migration and invasion in prostate cancer cells. Human Cell, 34(2), 607-623. https://doi.org/10.1007/s13577-020-00479-8

Jardaly, A., \& Gilbert, S. R. (2021). Combined antegrade femur lengthening and distal deformity correction: a case series. Journal of Orthopaedic Surgery and Research, 16(1), 1-7. https://doi.org/10.1186/s13018-020-02168-6

Karaoui, L. R., Ramia, E., Mansour, H., Haddad, N., \& Chamoun, N. (2021). Impact of pharmacistconducted anticoagulation patient education and telephone follow-up on transitions of care: a randomized controlled trial. BMC Health Services Research, 21(1), 1-12. https://doi.org/10.1186/s12913-021-06156-2

Khalife, J. J., Abbas, M. Al, \& Saab, S. S. (2020). Formation of policies guided by multivariable control theory. Operations Research Perspectives, 100148. https://doi.org/10.1016/j.orp.2020.100148

Khalifeh, M., Hobeika, R., El Hayek, L., Saad, J., Eid, F., El-Khoury, R., Ghayad, L. M., Jabre, V., Nasrallah, P., Barmo, N., Stephan, J. S., Khnayzer, R., Khalil, C., \& Sleiman, S. F. (2020). Nicotine induces resilience to chronic social defeat stress in a mouse model of water pipe tobacco exposure by activating BDNF signaling. Behavioural Brain Research, 382. https://doi.org/10.1016/j.bbr.2020.112499

Khalil, C., Chahine, J. B., Haykal, T., Al Hageh, C., Rizk, S., \& Khnayzer, R. S. (2021). E-cigarette aerosol induced cytotoxicity, DNA damages and late apoptosis in dynamically exposed A549 cells. Chemosphere, 263, 127874. https://doi.org/10.1016/j.chemosphere.2020.127874

Khoury, M. El, Haykal, T., Hodroj, M. H., Najem, S. A., Sarkis, R., Taleb, R. I., \& Rizk, S. (2020). Malva pseudolavatera leaf extract promotes ROS induction leading to apoptosis in acute myeloid leukemia cells in vitro. Cancers, 12(2), 435. https://doi.org/10.3390/cancers12020435

Kosmulski, M. (2012). The order in the lists of authors in multi-author papers revisited. Journal of Informetrics, 6(4), 639-644. https://doi.org/10.1016/j.joi.2012.06.006

Maalouf, J. T., Combs, J., Gillis, W. E., \& Perryman, A. (2020). Replicate or adapt? Franchising and organizational routines. Journal of Knowledge Management, 24(4), 775-798. https://doi.org/10.1108/JKM-09-2019-0493

Makke, G., Bitar, I., Salloum, T., Panossian, B., Alousi, S., Arabaghian, H., Medvecky, M., Hrabak, J., Merheb-Ghoussoub, S., \& Tokajian, S. (2020). Whole-Genome-Sequence-Based Characterization of Extensively Drug-Resistant Acinetobacter baumannii Hospital Outbreak. MSphere, 5(1). https://doi.org/10.1128/msphere.00934-19

Mansour, N., Bodman-Smith, K., Khnayzer, R. S., \& Daher, C. F. (2021). A photoactivatable Ru (II) complex bearing 2,9-diphenyl-1,10-phenanthroline: A potent chemotherapeutic drug inducing apoptosis in triple negative human breast adenocarcinoma cells. Chemico-Biological Interactions, 336. https://doi.org/10.1016/j.cbi.2020.109317

Mehanna, S., Bodman-Smith, K., Daher, C. F., \& Khnayzer, R. S. (2020). Rapid quantification of ruthenium(II) polypyridyl anti-cancer drugs using a selective ligand dissociation LC-MS/MS method. Analytical Methods, 12(37), 4517-4525. https://doi.org/10.1039/d0ay01250e

Melki, J., \& Hitti, E. (2021). The Domestic Tethering of Lebanese and Arab Women Journalists and News Managers. Journalism Practice, 288-307. https://doi.org/10.1080/17512786.2020.1715822

Metcalfe, B. D. (2008). Women, management and globalization in the Middle East. In Journal of Business Ethics (Vol. 83, Issue 1, pp. 85-100). Springer. https://doi.org/10.1007/s10551-007-9654-3

Morley, L. (2014). Lost leaders: Women in the global academy. Higher Education Research and Development, 33(1), 114-128. https://doi.org/10.1080/07294360.2013.864611 
Mourad, A., Tout, H., Wahab, O. A., Otrok, H., \& Dbouk, T. (2021). Ad Hoc Vehicular Fog Enabling Cooperative Low-Latency Intrusion Detection. IEEE Internet of Things Journal, 8(2), 829-843. https://doi.org/10.1109/JIOT.2020.3008488

Moussa, J., Panossian, B., Nassour, E., Salloum, T., Abboud, E., \& Tokajian, S. (2020). Detailed characterization of an IncFII plasmid carrying blaOXA-48 from Lebanon. Journal of Antimicrobial Chemotherapy, 75(9), 2462-2465. https://doi.org/10.1093/jac/dkaa181

Mrad, M., Majdalani, J., Cui, C. C., \& El Khansa, Z. (2020). Brand addiction in the contexts of luxury and fast-fashion brands. Journal of Retailing and Consumer Services, 55, 102089. https://doi.org/10.1016/j.jretconser.2020.102089

Nader, J., Afif, C., \& Louka, N. (2021). Impact of a novel partial defatting technology on oxidative stability and sensory properties of peanut kernels. Food Chemistry, 334, 127581. https://doi.org/10.1016/j.foodchem.2020.127581

Nasreddine, G., El-Sibai, M., \& Abi-Habib, R. J. (2020). Cytotoxicity of [HuArgI (co)-PEG5000]induced arginine deprivation to ovarian Cancer cells is autophagy dependent. Investigational New Drugs, 38(1), 10-19. https://doi.org/10.1007/s10637-019-00756-w

Nielsen, M. W., Alegria, S., Börjeson, L., Etzkowitz, H., Falk-Krzesinski, H. J., Joshi, A., Leahey, E., Smith-Doerr, L., Woolley, A. W., \& Schiebinger, L. (2017). Gender diversity leads to better science. In Proceedings of the National Academy of Sciences of the United States of America (Vol. 114, Issue 8, pp. 1740-1742). National Academy of Sciences. https://doi.org/10.1073/pnas.1700616114

O'Connor, P., \& Assaker, G. (2021). COVID-19's effects on future pro-environmental traveler behavior: an empirical examination using norm activation, economic sacrifices, and risk perception theories. Journal of Sustainable Tourism. https://doi.org/10.1080/09669582.2021.1879821

Said Saab, S., Hauser, M., Ray, A., \& Saab, S. S. (2021). Multivariable Nonadaptive Controller Design. IEEE Transactions on Industrial Electronics, 68(7), 6181-6191. https://doi.org/10.1109/TIE.2020.2998753

Saliba, E., Sayad, A., Alameddine, L., El-Haddad, K., \& Tannous, Z. (2021). Mycoplasma pneumonia and atypical acute hemorrhagic edema of infancy. American Journal of Emergency Medicine, 41, 266.e3-266.e5. https://doi.org/10.1016/j.ajem.2020.08.067

Salloum, T., Moussa, R., Rahy, R., Deek, J. Al, Khalifeh, I., Hajj, R. El, Hall, N., Hirt, R. P., \& Tokajian, S. (2020). Expanded genome-wide comparisons give novel insights into population structure and genetic heterogeneity of leishmania tropica complex. PLoS Neglected Tropical Diseases, 14(9), 1-27. https://doi.org/10.1371/journal.pntd.0008684

Salloum, T., Panossian, B., Bitar, I., Bitar, I., Hrabak, J., Hrabak, J., Araj, G. F., \& Tokajian, S. (2020). First report of plasmid-mediated colistin resistance mcr-8.1 gene from a clinical Klebsiella pneumoniae isolate from Lebanon. Antimicrobial Resistance and Infection Control, 9(1), 1-7. https://doi.org/10.1186/s13756-020-00759-w

Sami, H., \& Mourad, A. (2020). Dynamic On-Demand Fog Formation Offering On-the-Fly IoT Service Deployment. IEEE Transactions on Network and Service Management, 17(2), 1026-1039. https://doi.org/10.1109/TNSM.2019.2963643

Sanchez-Ruiz, M. J., El Ahmad, P., Karam, M., \& Saliba, M. A. (2021). Rape myth acceptance in Lebanon: The role of sexual assault experience/familiarity, sexism, honor beliefs, and the Dark Triad. Personality and Individual Differences, 170, 110403. https://doi.org/10.1016/j.paid.2020.110403

Sarouphim, K. M., \& Kassem, S. (2020). Use of the portage curriculum to impact child and parent outcome in an early intervention program in Lebanon. Early Years. https://doi.org/10.1080/09575146.2020.1818186

Sayyed, K., Hdayed, I., Tabcheh, M., Abdel-Razzak, Z., \& El-Bitar, H. (2020). Antioxidant properties of the Lebanese plant Iris $x$ germanica L. crude extracts and antagonism of chlorpromazine toxicity on Saccharomyces cerevisiae. Drug and Chemical Toxicology. https://doi.org/10.1080/01480545.2020.1810261 
Shebaby, W., Elias, A., Mroueh, M., Nehme, B., El Jalbout, N. D., Iskandar, R., Daher, J. C., Zgheib, M., Ibrahim, P., Dwairi, V., Saad, J. M., Taleb, R. I., \& Daher, C. F. (2020). Himachalol induces apoptosis in B16-F10 murine melanoma cells and protects against skin carcinogenesis. Journal of Ethnopharmacology, 253. https://doi.org/10.1016/j.jep.2020.112545

Shebaby, W., Saliba, J., Faour, W. H., Ismail, J., El Hage, M., Daher, C. F., Taleb, R. I., Nehmeh, B., Dagher, C., Chrabieh, E., \& Mroueh, M. (2021). In vivo and in vitro anti-inflammatory activity evaluation of Lebanese Cannabis sativa L. ssp. indica (Lam.). Journal of Ethnopharmacology, 270. https://doi.org/10.1016/j.jep.2020.113743

Sheltzer, J. M., \& Smith, J. C. (2014). Elite male faculty in the life sciences employ fewer women. Proceedings of the National Academy of Sciences of the United States of America, 111(28), 1010710112. https://doi.org/10.1073/pnas.1403334111

Shen, H. (2013). Inequality quantified: Mind the gender gap. In Nature (Vol. 494, Issue 7439, pp. $22-$ 24). https://doi.org/10.1038/495022a

Stratcom. (2019). About Title IX - Equity and Inclusion at LAU. Lebanese American University. https://titleix.lau.edu.lb/about/

Sweidan, Z., Islambouli, R., \& Sharafeddine, S. (2020). Optimized flow assignment for applications with strict reliability and latency constraints using path diversity. Journal of Computational Science, 44, 101163. https://doi.org/10.1016/j.jocs.2020.101163

Tannous, H., Istrate, D., Perrochon, A., Daviet, J. C., Benlarbi-Delai, A., Sarrazin, J., Ho Ba Tho, M. C., \& Dao, T. T. (2021). GAMEREHAB@HOME: A New Engineering System Using Serious Game and Multisensor Fusion for Functional Rehabilitation at Home. IEEE Transactions on Games, 13(1), 89-98. https://doi.org/10.1109/TG.2019.2963108

Tarhini, A., Balozain, P., \& Srour, F. J. (2021). Emergency management system design for accurate data: a cognitive analytics management approach. Journal of Enterprise Information Management, 34(2), 697-717. https://doi.org/10.1108/JEIM-11-2019-0366

Tay, B., \& Mourad, A. (2020). Intelligent Performance-Aware Adaptation of Control Policies for Optimizing Banking Teller Process Using Machine Learning. IEEE Access. https://ieeexplore.ieee.org/stamp/stamp.jsp?arnumber=9163345

Tohme, P., Grey, I., \& Abi-Habib, R. (2020). The Mental States Task (MST): Correlates and New Perspectives on Mentalizing in a Lebanese Student Sample. Journal of Personality Assessment. https://doi.org/10.1080/00223891.2020.1769114

Tscharntke, T., Hochberg, M. E., Rand, T. A., Resh, V. H., \& Krauss, J. (2007). Author sequence and credit for contributions in multiauthored publications. In PLoS Biology (Vol. 5, Issue 1, pp. 00130014). Public Library of Science. https://doi.org/10.1371/journal.pbio.0050018

USAID. (2019). Gender Analysis of Basic Public Education in Lebanon. https://pdf.usaid.gov/pdf_docs/pa00mz43.pdf

Wahab, O. A., Bentahar, J., Otrok, H., \& Mourad, A. (2021). Resource-Aware Detection and Defense System against Multi-Type Attacks in the Cloud: Repeated Bayesian Stackelberg Game. IEEE Transactions on Dependable and Secure Computing, 18(2), 605-622. https://doi.org/10.1109/TDSC.2019.2907946

Wakim, V., Abi Khalil, E., Salloum, A. K., Khazen, G., Ghassibe-Sabbagh, M., \& Zalloua, P. A. (2021). New susceptibility alleles associated with severe coronary artery stenosis in the Lebanese population. BMC Medical Genomics, 14(1), 1-11. https://doi.org/10.1186/s12920-021-00942-x

West, J. D., Jacquet, J., King, M. M., Correll, S. J., \& Bergstrom, C. T. (2013). The Role of Gender in Scholarly Authorship. PLoS ONE, 8(7), e66212. https://doi.org/10.1371/journal.pone.0066212

Wren, J. D., Kozak, K. Z., Johnson, K. R., Deakyne, S. J., Schilling, L. M., \& Dellavalle, R. P. (2007). The write position. A survey of perceived contributions to papers based on byline position and 
number of authors. In EMBO Reports (Vol. 8, Issue 11, pp. 988-991). John Wiley \& Sons, Ltd. https://doi.org/10.1038/sj.embor.7401095

Yacoubian, H. A. (2021). Students' Views of Nature of Science: A Long-term Study. Science and Education, 30(2), 381-408. https://doi.org/10.1007/s11191-020-00179-7

Yammine, K., \& Assi, C. (2020). Educational assessment of the major lower limb amputations videos on YouTube. Vascular, 28(5), 536-541. https://doi.org/10.1177/1708538120918423 


\section{Appendix}

\begin{tabular}{|c|c|c|c|c|}
\hline Article & $\begin{array}{l}\text { Last } \\
\text { Author } \\
\text { Gender }\end{array}$ & $\begin{array}{l}\text { First Author } \\
\text { Gender }\end{array}$ & General Subject Area & Year \\
\hline (Maalouf et al., 2020) & $\mathrm{F}$ & $\mathrm{F}$ & Business \& Management & 2020 \\
\hline (Mrad et al., 2020) & $\mathrm{F}$ & $\mathrm{F}$ & Business \& Management & 2020 \\
\hline (Assaker et al., 2020) & $\mathrm{F}$ & $\mathrm{M}$ & Business \& Management & 2020 \\
\hline (M. F. Farah \& Ramadan, 2020) & $\mathrm{M}$ & $\mathrm{F}$ & Business \& Management & 2020 \\
\hline (M. F. Farah \& Shahzad, 2020) & $\mathrm{M}$ & $\mathrm{F}$ & Business \& Management & 2020 \\
\hline (Antar \& Elkhoury, 2020) & $\mathrm{F}$ & $\mathrm{M}$ & Engineering & 2020 \\
\hline (Mehanna et al., 2020) & M & $\mathrm{F}$ & Engineering & 2020 \\
\hline (Sami \& Mourad, 2020) & $\mathrm{M}$ & $\mathrm{M}$ & Engineering & 2020 \\
\hline (Makke et al., 2020) & $\mathrm{F}$ & $\mathrm{F}$ & Medicine \& life Sciences & 2020 \\
\hline (Moussa et al., 2020) & $\mathrm{F}$ & $\mathrm{F}$ & Medicine \& life Sciences & 2020 \\
\hline (Salloum, Moussa, et al., 2020) & $\mathrm{F}$ & $\mathrm{F}$ & Medicine \& life Sciences & 2020 \\
\hline (Salloum, Panossian, et al., 2020) & $\mathrm{F}$ & $\mathrm{F}$ & Medicine \& life Sciences & 2020 \\
\hline (M. El Khoury et al., 2020) & $\mathrm{F}$ & $\mathrm{F}$ & Medicine \& life Sciences & 2020 \\
\hline (Sayyed et al., 2020) & $\mathrm{F}$ & $\mathrm{F}$ & Medicine \& life Sciences & 2020 \\
\hline (Doumit et al., 2020) & $\mathrm{F}$ & $\mathrm{F}$ & Medicine \& life Sciences & 2020 \\
\hline (Bilen et al., 2020) & $\mathrm{F}$ & $\mathrm{F}$ & Medicine \& life Sciences & 2020 \\
\hline (Khalifeh et al., 2020) & $\mathrm{F}$ & M & Medicine \& life Sciences & 2020 \\
\hline (Hodroj et al., 2020) & $\mathrm{F}$ & M & Medicine \& life Sciences & 2020 \\
\hline (Dagher-Hamalian et al., 2020) & $\mathrm{M}$ & $\mathrm{F}$ & Medicine \& life Sciences & 2020 \\
\hline (Nasreddine et al., 2020) & $\mathrm{M}$ & $\mathrm{F}$ & Medicine \& life Sciences & 2020 \\
\hline (Abi-Gerges et al., 2020) & $\mathrm{M}$ & $\mathrm{F}$ & Medicine \& life Sciences & 2020 \\
\hline (El Hajj et al., 2020) & $\mathrm{M}$ & $\mathrm{F}$ & Medicine \& life Sciences & 2020 \\
\hline (Diab et al., 2020) & $\mathrm{M}$ & $\mathrm{F}$ & Medicine \& life Sciences & 2020 \\
\hline (Ahdab et al., 2019) & $\mathrm{M}$ & $\mathrm{M}$ & Medicine \& life Sciences & 2020 \\
\hline (Yammine \& Assi, 2020) & $\mathrm{M}$ & $\mathrm{M}$ & Medicine \& life Sciences & 2020 \\
\hline (Assi et al., 2020) & $\mathrm{M}$ & $\mathrm{M}$ & Medicine \& life Sciences & 2020 \\
\hline (Assi et al., 2021) & M & $\mathrm{M}$ & Medicine \& life Sciences & 2020 \\
\hline (Shebaby et al., 2020) & $\mathrm{M}$ & M & Medicine \& life Sciences & 2020 \\
\hline (Al Haddad et al., 2020) & $\mathrm{F}$ & $\mathrm{F}$ & Natural Sciences & 2020 \\
\hline (Idriss et al., 2020) & $\mathrm{F}$ & $\mathrm{F}$ & Natural Sciences & 2020 \\
\hline (Sweidan et al., 2020) & $\mathrm{F}$ & $\mathrm{F}$ & Natural Sciences & 2020 \\
\hline (E. Issa et al., 2020) & $\mathrm{F}$ & $\mathrm{M}$ & Natural Sciences & 2020 \\
\hline (Elaridi et al., 2020) & $\mathrm{M}$ & $\mathrm{F}$ & Natural Sciences & 2020 \\
\hline (Al-Alam et al., 2020) & $\mathrm{M}$ & $\mathrm{F}$ & Natural Sciences & 2020 \\
\hline (Tohme et al., 2020) & M & $\mathrm{F}$ & Natural Sciences & 2020 \\
\hline (Tay \& Mourad, 2020) & $\mathrm{M}$ & M & Natural Sciences & 2020 \\
\hline (Khalife et al., 2020) & $\mathrm{M}$ & $\mathrm{M}$ & Natural Sciences & 2020 \\
\hline (J. S. Issa \& Habchi, 2020) & $\mathrm{M}$ & M & Natural Sciences & 2020 \\
\hline
\end{tabular}




\begin{tabular}{|c|c|c|c|c|}
\hline (Fakhoury, 2021) & $\mathrm{F}$ & $\mathrm{F}$ & Social Sciences & 2020 \\
\hline (Sarouphim \& Kassem, 2020) & $\mathrm{F}$ & $\mathrm{F}$ & Social Sciences & 2020 \\
\hline (Bouclaous et al., 2021) & $\mathrm{F}$ & $\mathrm{F}$ & Social Sciences & 2020 \\
\hline (Melki \& Hitti, 2021) & $\mathrm{F}$ & M & Social Sciences & 2020 \\
\hline (Al-Abbas et al., 2020) & $\mathrm{M}$ & $\mathrm{M}$ & Social Sciences & 2020 \\
\hline (Tarhini et al., 2021) & $\mathrm{F}$ & $\mathrm{M}$ & Business \& Management & 2021 \\
\hline (Dabbous \& Tarhini, 2021) & M & $\mathrm{F}$ & Business \& Management & 2021 \\
\hline (Antounian et al., 2021) & M & $\mathrm{F}$ & Business \& Management & 2021 \\
\hline (Al-Abbas \& Saab, 2021) & M & M & Business \& Management & 2021 \\
\hline (Bouri, Saeed, et al., 2021) & $\mathrm{M}$ & M & Business \& Management & 2021 \\
\hline (Bouri, Lucey, et al., 2021) & M & M & Business \& Management & 2021 \\
\hline (Aoun Barakat et al., 2021) & M & $\mathrm{F}$ & Engineering & 2021 \\
\hline (El-Rajab \& Abou-Rjeily, 2021) & M & $\mathrm{F}$ & Engineering & 2021 \\
\hline (N. Farah \& Ghadboun, 2021) & $\mathrm{M}$ & $\mathrm{M}$ & Engineering & 2021 \\
\hline (Wahab et al., 2021) & M & M & Engineering & 2021 \\
\hline (Mourad et al., 2021) & M & M & Engineering & 2021 \\
\hline (Assaad et al., 2021) & M & M & Engineering & 2021 \\
\hline (Said Saab et al., 2021) & $\mathrm{M}$ & $\mathrm{M}$ & Engineering & 2021 \\
\hline (Tannous et al., 2021) & $\mathrm{M}$ & $\mathrm{M}$ & Engineering & 2021 \\
\hline (El-Mais et al., 2021) & $\mathrm{F}$ & $\mathrm{F}$ & Medicine \& life Sciences & 2021 \\
\hline (Berro et al., 2021) & $\mathrm{F}$ & $\mathrm{F}$ & Medicine \& life Sciences & 2021 \\
\hline (Feghali et al., 2021) & $\mathrm{F}$ & $\mathrm{F}$ & Medicine \& life Sciences & 2021 \\
\hline (Saliba et al., 2021) & $\mathrm{F}$ & M & Medicine \& life Sciences & 2021 \\
\hline (Di Lernia \& Ricci, 2015) & $\mathrm{F}$ & M & Medicine \& life Sciences & 2021 \\
\hline (Harhous et al., 2021) & M & $\mathrm{F}$ & Medicine \& life Sciences & 2021 \\
\hline (Karaoui et al., 2021) & M & $\mathrm{F}$ & Medicine \& life Sciences & 2021 \\
\hline (Mansour et al., 2021) & $\mathrm{M}$ & $\mathrm{F}$ & Medicine \& life Sciences & 2021 \\
\hline (Wakim et al., 2021) & $\mathrm{M}$ & $\mathrm{M}$ & Medicine \& life Sciences & 2021 \\
\hline (Jardaly \& Gilbert, 2021) & M & M & Medicine \& life Sciences & 2021 \\
\hline (Shebaby et al., 2021) & M & M & Medicine \& life Sciences & 2021 \\
\hline (Hanna et al., 2021) & $\mathrm{F}$ & $\mathrm{F}$ & Natural Sciences & 2021 \\
\hline (Jaafar et al., 2021) & $\mathrm{F}$ & $\mathrm{F}$ & Natural Sciences & 2021 \\
\hline (EL-CHAMI et al., 2021) & $\mathrm{F}$ & $\mathrm{F}$ & Natural Sciences & 2021 \\
\hline (Itani \& Chaker, 2021) & $\mathrm{F}$ & $\mathrm{M}$ & Natural Sciences & 2021 \\
\hline $\begin{array}{l}\text { (Chmaisani \& Elmoussaoui, } \\
\text { 2021) }\end{array}$ & $\mathrm{F}$ & M & Natural Sciences & 2021 \\
\hline (Elaridi et al., 2021) & $\mathrm{M}$ & $\mathrm{F}$ & Natural Sciences & 2021 \\
\hline (Nader et al., 2021) & M & $\mathrm{F}$ & Natural Sciences & 2021 \\
\hline (C. Al Khoury, 2021) & M & M & Natural Sciences & 2021 \\
\hline (Bouri, Gupta, et al., 2021) & M & M & Natural Sciences & 2021 \\
\hline (Khalil et al., 2021) & $\mathrm{M}$ & $\mathrm{M}$ & Natural Sciences & 2021 \\
\hline (Eslami et al., 2021) & M & M & Natural Sciences & 2021 \\
\hline
\end{tabular}


Oneissi \& Al-Abbas / Sustainable Gender Equity Influenced by an Americanized....

\begin{tabular}{lllll}
\hline (Sanchez-Ruiz et al., 2021) & F & F & Social Sciences & 2021 \\
\hline (Djoundourian, 2021) & F & F & Social Sciences & 2021 \\
\hline (Dibeh et al., 2021) & F & M & Social Sciences & 2021 \\
\hline (Yacoubian, 2021) & M & M & Social Sciences & 2021 \\
\hline (O'Connor \& Assaker, 2021) & M & M & Social Sciences & 2021 \\
\hline
\end{tabular}

